\title{
Small Farmers and Resource-Conserving Agriculture: The Prospect of Attaining Environmental Sustainability through Zero Tillage Relay Cropping in Bangladesh
}

\author{
Zuberi MII*, Hossain $\mathrm{S}^{1}$, Ali $\mathrm{O}^{2}$ and Akhtar $\mathrm{N}^{3}$ \\ ${ }^{1}$ Gono University, Savar, Dhaka 1344, Bangladesh \\ 2Bangladesh Agricultural Research Institute, Gazipur, Bangladesh \\ ${ }^{3}$ Satkhira Government College, Bangladesh
}

Research Article

Volume 3 Issue 5

Received Date: June 10, 2018

Published Date: June 22, 2018

*Corresponding author: Muhammad Iqbal Zuberi, Gono University, Savar, Dhaka 1344, Bangladesh, Email: iqbal.zuberi@gmail.com

\section{Abstract}

Food systems and the ability to attain food security have already been affected by land degradation, environmental pollution and global climate change. With more time, agriculture will have greater difficulty in producing enough, good quality food to sustain the growing human population. The new paradigm shift and set of practices in the field of agriculture today has been identified - variously termed as 'climate-smart agriculture' , 'regenerative agriculture', 'organic' or ' resource-conserving agriculture' proven to meet the promise of food security, but there is a need of practical evidence and bold action. Demonstration of the links these agricultural approaches possess to many benefits accruing to food production, security, human and environmental health are urgently needed. Reported research documented two cases from Bangladesh. Currently a number of obstacles to introduce, adopt and scaling up of these practices on a global scale exist and only a small percentage of concerned farmers, researchers, land managers, consumers and policy makers are familiar to this alternative approach to safeguard our common future.

Keywords: Resource-Conserving Agriculture; Zero Tillage; Relay Cropping; Lentil; Wheat; Bangladesh

\section{Introduction}

Throughout the developing world, as population pressure increases and land holdings shrink, many poor smallholders have resorted to more frequent cropping and intensive agriculture, curtailing traditional long fallows degrading land and reducing production. The
U.N.'s Report "The State of Food and Agriculture 2014" states that more than 80 percent of the world's food is still produced by small family farmers, there are more than 500 million family farms manage between 70 and 80 percent of the world's agricultural land; Small and medium sized farms tend to have higher crop yields per hectare than larger operations, the report said as they 


\section{Open Access Journal of Agricultural Research}

manage resources and use labor more intensively [http://farmlandgrab.org/24073]. With the spread of Green Revolution technologies an increased production has been achieved, like with cereal yields in East Asia and the Pacific nearly tripling, these modern agriculture technologies are found associated with greenhouse gas emissions, pesticide residues, reduced biodiversity, soil erosion, declining fertility and salt build-ups [1-5]. As the world's population tracks towards 9 billion by 2050, increased competition for fixed land and water resources will surely pose problems for maintaining continued productivity increases required to meet food needs. Moreover, with green house gas emission increasing and energy supplies declining, this use of increasing quantities of inorganic nitrogen in modern agriculture presents a serious challenge to sustainability [6].

Bangladesh has managed to accelerate overall GDP growth by one percentage point on average every decade - from $3 \%$ in the 1970 s to $6 \%$ in the last 10 years [7]. Still $73 \%$ of about 120 million Bangladeshis live in rural areas and agriculture is the single largest producing sector of the economy comprising about $18.6 \%$ (in 2010) of the country's GDP and employing around $45 \%$ of the total labor force [7]. Within that, 57\% of the agricultural GDP comes from crops, with forestry, fisheries, and livestock making up the remainder. Seventy-five percent of Bangladesh's cropland is devoted to rice, being the staple food of Bangladesh, rice accounts for $76 \%$ of the cultivated area, $78 \%$ of the irrigated area, $52 \%$ of agricultural GDP, and $71 \%$ of caloric intake $[8,9]$. During recent decades rice productivity stagnated or even declined in many areas in Bangladesh due to various reasons, intensifying already widespread poverty-related food insecurity, added by the soaring prices of key staples. However, traditionally, many small farmers continue to maintain a sequence in crop rotation growing pulses or oilseeds after rice which are mainly rain-fed. Leguminous pulses recover nutrients consumed by rice earlier, maintaining productivity of land. This strategy of prudently exploiting local inputs and ecological processes rather than using external inputs has particular relevance to future food security in the light of rising food prices and agricultural inputs as well as increasing competition for land, water and energy. For example, the long-term rises in costs of fertilizer-pesticides and irrigation will continue to increase the expenditure of food and making it increasingly unaffordable for the poor. It is smallholders' low input production system which now feed much of the world's poor and who will continue to bear much of the world's future demand for food if remain productive. Also relevant is the fact that struggling small farmers all over the developing world have already been hit hard by climate variability, losing harvests and livestock to drought, floods and struggling to survive amid changing rainfall patterns. Crop productivity is expected to decrease "for even small local temperature increases $(1$ $-2^{\circ} \mathrm{C}$ )" [10]. According to the IPCC, Bangladesh is slated to lose the largest amount of cultivated land globally due to rising sea levels. A $1 \mathrm{~m}$ rise in sea levels would inundate 20 percent of the country's landmass. Within the next 50 years, over 20 million people could be displaced and become "climate change refugees" if sea and salinity levels rise in Bangladesh, according to the government's 2009 Bangladesh Climate Change Strategy and Action Plan. There is an important need of in depth research and closer scrutiny of what the local communities are thinking about this change, what the small farmers can do as adaptations and possible interventions/future investments needed to deliver sustainable results [4].

Against this backdrop, research suggested that 'climate-smart agriculture', 'regenerative agriculture', 'organic' or ' resource-conserving agriculture' have sound potential for improving livelihoods of smallholders and contribute to sustainable agricultural production and food security [11-13]. A recent report asserts that as the human society inevitably face increasingly constrained agricultural resources, these 'eco-agricultural approaches' will take on more urgent priority [14]. Resourceconserving agriculture makes the best use of natural goods and services without compromising their future use, and promotes social, environmental and health goals along with productivity gains. Many of these practices are commonly part of traditional agriculture which includes integrated pest and nutrient management, conservation tillage, agro forestry, aquaculture, water harvesting and livestock integration. All these practices/technologies facilitate soil replenishment using locally available organic fertilizers, cover crops, use of nitrogen-fixing legumes, crop rotations, and mulches; zero/reduced tillage, improved water management; and crop diversification to reduce the risk of crop failure. Traditional/resource conserving agriculture does not exclude synthetic agrochemicals if they improve productivity without harming the environment [15]. These alternative systems of agriculture can provide benefits in many different ways: by increasing productivity, by reducing costs, by saving environment from degradation; also when 'organic' by increasing product prices. Recent economic crisis resulted in a permanent increase in the cost of fertilizers - by $200 \%$ for 


\section{Open Access Journal of Agricultural Research}

nitrogen fertilizers in 2007- suggesting that maintaining or changing to traditional/resource conserving agriculture will result in huge cost savings and also help poor, small farmers to survive and sustain food production in remote areas [16]. Recently, Mica Bennett and Steven Franzel examined 31 documented cases of African and Latin American farmers adopting 'organic resource conserving agriculture' and found that yield improved in 19 of the 25 cases that reported on it, food security improved in seven of eight cases, and net income improved in 19 of 23 cases [17]. They observed that successful 'resource conserving agriculture' initiatives do not occur spontaneously rather require a variety of skills from smallholders and their allies which include adaptive farm management, effective producer organizations, entrepreneurship, capacity to innovate, value addition and boundary spanning, these being noted in the case of traditional farming in Ethiopia [18].

The majority of small farmers grow, follow 'resource conserving agriculture' in that, the rainfed pulses, oil seeds, wheat, spices and vegetables grown during the winter (rabi) after harvesting the rainy season aman rice need minimum external resources. But very often, delayed withdrawal of the monsoon and/or flooding results in late harvest of paddy, thereby also delaying land preparation, sowing of the winter crops like lentil and wheat. Because of the short winter, the delay of every successive day in planting beyond November decreases the growing period and residual soil moisture thus drastically reducing grain yield $[19,20]$. Wheat, also a winter (rabi) crop, faces a number of stress factors like short growing season, drought, higher temperature as well as salinity near the coastal areas of Bangladesh (Fig1). Also the farmers here experience very low yield rates due to intensifying salinity stress due to river water decline and sea level rise. No suitable wheat or lentil variety is known for the stressed environment though about 2.8 million hectares of land (one-fifth of the total cultivable land) of Bangladesh is known to be salt affected where only Aman rice can be grown in more salt-affected areas during the monsoon when the salinity decreases due to rain and flood water [21]. Only in low saline areas, after harvesting Aman rice, farmers prepare the land when the soil is ready for winter crops. Often, land preparation needs time and resources, also within a short period the stored moisture in soil becomes inadequate to meet the evapotranspiration (ET) demand of the crop and consequently the crops like wheat undergoes moisture stress of varying intensities [22]. In salinity affected areas supplementary irrigation is difficult and expensive. The district of Satkhira (Figure 1) is one of the South-Western district of Bangladesh which in salinity affected being adjacent to the Bay of Bengal.

Therefore, to avoid delay in planting and reduce the cost of production, farmers need to avoid plowing and land preparation so the prospect of zero tillage and relay cropping or surface seeding in lentil and wheat was explored. Depending on the withdrawal of rain and drying up of land for plowing, no till relay sowing of these crops could be accomplished 15 to 35 days earlier than in conventional tillage and land preparation method. In this study we report two cases how this resource conserving agriculture can contribute to sustainable food production system furthering progress towards food security in Bangladesh with little input.

\section{Materials and Methods}

We used to sets of experimental evidences from two research projects with lentil) and wheat carried out for higher degree (Rajshahi University, Bangladesh) [19,23]. As lentil and wheat are grown during the winter (rabi) season after the harvesting rainy season 'aman' paddy (end of October/ early November), often late harvest of the paddy due to late withdrawal of the monsoon or flood water delay drying of soil, preparation of land and sowing all become late. As the winter is short and mild (December to February) in Bangladesh and the residual moisture in the soil dries out rapidly, higher temperature and aridity all affect growth and yield of the crops. Also, traditional plowing and harrowing often result in soil loss due to wind/water erosion.

In the lentil experiment, direct broadcasting of the lentil seeds was done in the paddy field prior to harvest, which avoided the delay due to land preparation in the Agriculture Research Farm, Ishurdi, Pabna, Bangladesh (Figure 1). Two sets of replicated (three) field trials were conducted during the rabi seasons of 2009 and 2010 to test the prospect of lentil relay cropping and to find out the suitable management for better plant establishment and yield. Also the prospect of lentil relay cropping was tested in the farmer's field of three adjacent Districts in the North-western Bangladesh (Pabna, Natore and Kushtia) in 2010-11 to validate the experimental findings and to create awareness among the farmers. 


\section{Open Access Journal of Agricultural Research}

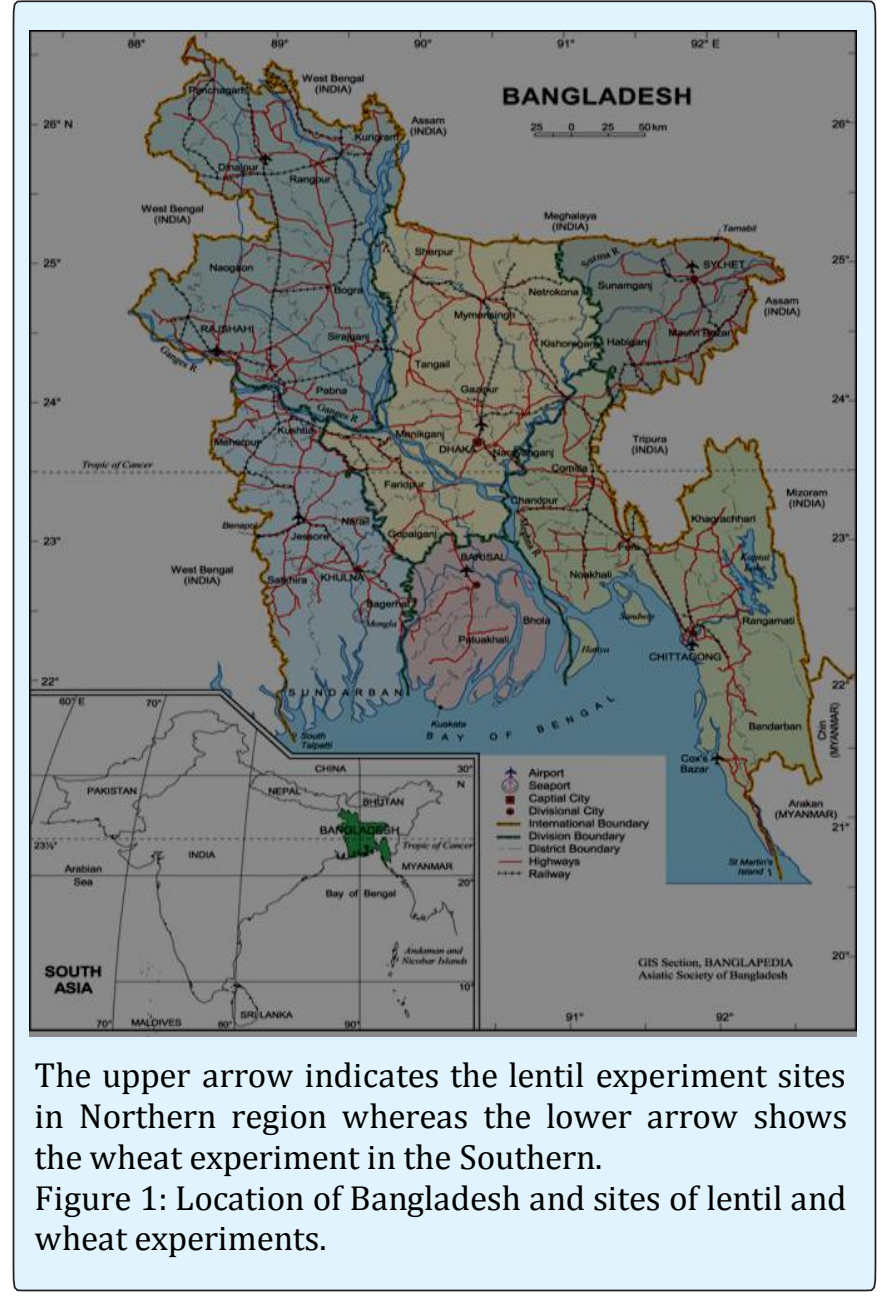

Lentil seeds were sown in the paddy field on November 1 to 3, 2009 and 2010 in the experimental plots (three replications) and rice was harvested after 7 days keeping the stubbles at about $30 \mathrm{~cm}$ height from the ground. The lentil crop was harvested during the first week of March (March, 4, 5 and 6) when about $80 \%$ of the lentil plants and pod turned to straw colored. Data collected on yield and related traits from plants of $1 \mathrm{~m} 2$ at three locations in a field and seeds and straw yield were converted into $\mathrm{kg} / \mathrm{ha}$ and $\mathrm{t} / \mathrm{ha}$.

The wheat experiment was conducted in the paddy fields of high salinity affected area in the South-eastern coastal belt of Bangladesh in the Shyamnagar sub-district during the winter seasons of 2010 and 2011. The wheat seed (HYV Kanchan) of about $0.5 \mathrm{~kg}$ were collected from the authorized dealer from Shyamnagar and were broadcast in the paddy field on November 18, just 18 days before harvesting of the paddy. The stubbles were kept at the height of $15 \mathrm{~cm}$ in the field. Electro Conductivity Meter model HI-993310-Hanna, (1344.88) was used to measure electrical conductivity in the more saline and less-saline areas, about 350 gm soil samples from (a) soil surface (b) $13 \mathrm{~cm}$ depth and (c) $25 \mathrm{~cm}$ depth, were collected between the months of November, 2008 to April 2009.

A paddy field of about $16 \times 10 \mathrm{~m}$ was selected in Shyamnagar (Figure 2) high salinity affected area, wheat seed were broadcast in the paddy field on November 18, 2009, 18 days before harvesting the paddy. During harvesting the paddy, the stubbles were kept at the height of $15 \mathrm{~cm}$ in the field. It is usual practice for wheat growers to give some irrigation and fertilizer for a better yield, but in the present experiment no irrigation and inorganic fertilizers were used. The data collected from the relay crop on individual plant basis from $1 \mathrm{sq} \mathrm{m}$ areas of the farmer's plot for data collection.

\section{Results and Discussion}

\section{Smart Agriculture: Relay Cropping of Lentil to Overcome Climate Irregularity}

The results (Table1) showed that relay cropping of lentil with high yielding variety (X95S-167 (4) gave a significantly higher yield under relay cropping than the local varieties, also in the farmers' field the yield was high but lower than the experimental field. This result indicated that relay cropping with modern variety will be more profitable, it was estimated that a net return from relay cropping would vary between $6400-6700 \mathrm{Tk} / \mathrm{ha}$ with modern variety whereas between $4400 \mathrm{Tk} / \mathrm{ha}$ from local variety (data not shown). Similar result were also reported by Gahoonia, et al. Ali, et al., it was identified that under higher rice straw height $(15 \mathrm{~cm})$ resulted in better crop growth environment. In some areas, the relay-sown lentil yielded nearly compared to traditionally practiced sole cultivation after T.aman harvest [24-27]. Lentil, being an economically and nutritionally important crop, its production can benefit from relay sowing into late T.aman crops, so the spread of relay sowing of lentil into standing T. aman rice has to be widely adopted. But only very limited advance has so far achieved with efforts from ICARDA, CYMMIT, ACIAR, BRRI so far (http://aciar.gov.au/project/cim/2009/038). 


\section{Open Access Journal of Agricultural Research}

\begin{tabular}{|c|c|c|c|c|}
\hline Treatment & $\begin{array}{c}\text { Plant population at } \\
\text { harvest }\left(\mathbf{m}^{\mathbf{2})}\right.\end{array}$ & Pods/plant & Grain yield (kg/ha) & Straw yield (t/ha) \\
\hline Local variety No fertilizer & $163 \mathrm{~A}$ & $53.67 \mathrm{~B}$ & $900 \mathrm{~F}$ & $1.20 \mathrm{~J}$ \\
\hline Local variety Fertilizer + & $165 \mathrm{~A}$ & $58.0 \mathrm{C}$ & $1,077 \mathrm{G}$ & $1.30 \mathrm{~J}$ \\
\hline High yield variety 0 fertilizer & $163 \mathrm{~A}$ & $72.0 \mathrm{D}$ & $1,485 \mathrm{H}$ & $2.30 \mathrm{~K}$ \\
\hline High yield variety Fertilizer + & $164 \mathrm{~A}$ & $86.0 \mathrm{E}$ & $1,513 \mathrm{I}$ & $2.40 \mathrm{~L}$ \\
\hline Results from farmers' field Local variety & 262 & --- & 1160 & 1.77 \\
\hline $\begin{array}{c}\text { Results from farmers' field High yield } \\
\text { variety }\end{array}$ & 265 & --- & 1475 & 2.21 \\
\hline
\end{tabular}

*DMRT: figures having similar letter do not differ significantly (5\% level).

Table 1: Performance of a local variety and a high yielding variety (X95S-167 (4) of lentil in experimental plot and farmers' plots (average of three locations) under zero tillage- relay seeding (rice straw height was $30 \mathrm{~cm}$ and seeding rate $30 \mathrm{~kg} / \mathrm{ha})^{*}$.

\section{Relay Cropping To Avoid Salinity Build Up With Climate Change}

The site of the wheat experiment was in Southern coast of the Bay of Bengal, near the Sundaram (Table 2). As determined prior to the trials, in the more saline area, the mean salinity in soil differed: in the surface it was 8.63 dS, at $13 \mathrm{~cm}$ depth $6.85 \mathrm{dS}$ and $5.99 \mathrm{dS}$ at $25 \mathrm{~cm}$ depth (each mean of six determinations over Nov 2009 to April 2010). But in the less saline areas these means were 5.55, 3.87 and $3.27 \mathrm{dS}$ respectively. Mean salinity also differed with season, in November 2009 the average of surface, mid and $25 \mathrm{~cm}$ depth was $5.28 \mathrm{dS}$ increasing gradually to 8.54 dS during April 2010 in the more saline areas, whereas from $4.03 \mathrm{dS}$ to $4.49 \mathrm{dS}$ in the less saline areas (Table 2). So, the field study indicated that soil salinity level was low in the less saline area but was high (6 to 8 $\mathrm{dS}$ ) and varied with time in the more saline area, increasing during the dry months (March/April). Extreme salinity ( $>5 \mathrm{dS}$ ) was usually known to affect crops severely [28].

\begin{tabular}{|c|c|c|c|c|c|c|c|c|}
\hline \multirow{2}{*}{ Month } & \multicolumn{4}{|c|}{ Saline } & \multicolumn{4}{c|}{ Less-saline } \\
\cline { 2 - 9 } & Surface & 13 cm depth & $\mathbf{2 5}$ cm depth & Mean & surface & 13 cm depth & 25 cm depth & Mean \\
\hline Nov. '09 & 7.55 & 5.6 & 4.88 & 6.01 & 4.2 & 2.42 & 1.4 & 2.67 \\
\hline Dec. '09 & 7.82 & 5.7 & 5.12 & 6.21 & 3.2 & 2.2 & 1.2 & 2.2 \\
\hline Jan. '10 & 8.2 & 6.8 & 5.23 & 6.74 & 3.2 & 2.4 & 1.4 & 2.33 \\
\hline Feb. '10 & 8.58 & 6.82 & 5.3 & 6.9 & 3.3 & 2.5 & 1.4 & 2.4 \\
\hline Mar. '10 & 8.93 & 7.31 & 6.12 & 7.45 & 3.4 & 2.5 & 1.5 & 2.47 \\
\hline April'10 & 10.12 & 7.82 & 6.85 & 8.26 & 3.6 & 2.5 & 1.62 & 2.57 \\
\hline Mean & 8.53 & 6.68 & 5.58 & & 3.48 & 2.42 & 1.42 & \\
\hline
\end{tabular}

$\mathrm{dS}=$ Deci Semen per meter.

Table 2: Salinity levels of soil (dS) from selected fields of Saline and less saline areas in Shyamnagar.

The result (Table 3) indicated that relay cropping was indeed helpful in combating salinity stress, while growing wheat with zero tillage. A yield of 5.5 gm per plant was obtained and the performance of the morphological characters (plant height, number of tillers, number of florets, the number and weight of the grains in the main head) were found to be higher compared to the performances in the local farmers' fields, who grew small quantities of wheat under salinity for subsistence. Therefore, wheat relay cropping may be a suitable alternative for increased wheat production by small farmers in T-Aman paddy after harvest. As the seeds used were collected from the local farmers' who kept seeds of the modern varieties in mixed state, data collected in 2011 indicated an average yield of $4.2 \mathrm{gm}$. per plant in saline and $6.8 \mathrm{gm}$. in less saline soil. 


\section{Open Access Journal of Agricultural Research}

The data from the local farmers' fields also indicated comparable results (number of tillers per plant ranging from 2.2 to 3.3 in saline and 2.8 to 3.8 in less saline, and wheat yield of 2.5 to $4.5 \mathrm{~g}$ per plant in the saline to 4.1 to $6.3 \mathrm{~g}$ in less saline area). These results suggest that the performance in the wheat grown in the farmer's field are not very different in performance and that they may are adjusting to the salinity and drought stresses existing in their environment.

\begin{tabular}{|c|c|c|c|c|c|c|c|}
\hline Treatment & $\begin{array}{c}\text { Plant height } \\
\text { at harvest } \\
\text { (cm) }\end{array}$ & $\begin{array}{c}\text { Number of } \\
\text { tillers at } \\
\text { harvest }\end{array}$ & $\begin{array}{c}\text { Flag leaf area } \\
\left(\mathbf{c m}^{2} \text { ) at heading }\right.\end{array}$ & $\begin{array}{c}\text { number of florets full grains in weight of full } \\
\text { main head at } \\
\text { harvest }\end{array}$ & $\begin{array}{c}\text { Yield per } \\
\text { main head at } \\
\text { harvest }\end{array}$ & $\begin{array}{c}\text { grains main } \\
\text { head (gm) }\end{array}$ & $\begin{array}{c}\text { plant } \text { (gm) } \\
\text { Relay cropping }\end{array}$ \\
97.12 & 2.7 & 56.61 & 20.3 & 39.35 & 2.62 & 5.47 \\
\hline $\begin{array}{c}\text { Farmer' less } \\
\text { saline }\end{array}$ & 94.33 & 2.21 & 48.54 & 17.53 & 36.63 & 1.12 & 3.73 \\
\hline $\begin{array}{c}\text { Farmer's more } \\
\text { saline }\end{array}$ & 81.55 & 2.06 & 33.01 & 16.23 & 34.09 & 1 & 3.17 \\
\hline LSD (P 0.05) & 3.21 & 0.3 & 4.31 & 1.32 & 2.59 & 0.62 & 0.49 \\
\hline
\end{tabular}

Table 3: Plant characters of wheat grown in the farmer's fields in saline, less saline and in the relay crop fields at Shyamnagar in the winter of 2009-2010 $(\mathrm{N}=20)$.

The main obstacle for growing wheat in the coastal areas is salinity and short winter. Fresh water for irrigation is unobtainable everywhere in this part of the country, the people depend on surface water from ponds for drinking and other domestic uses. This water scarcity imposes huge reductions in crop yield and is a limitation to crop expansion and the scenarios for global environmental change suggest a future increase in aridity as well as in the frequency of extreme events all over the earth including Bangladesh [10]. Nowadays, approximately $70 \%$ of the global available water is employed in agriculture and $40 \%$ of the world's food is produced in irrigated soil. More then $10 \%$ of the irrigation water comes from aquifers, leading to many aquifers exploited unsustainably [29].

\section{Advantages of Zero Tillage Relay Cropping}

So, the relay cropping may be an affordable solution for the small farmers in the Northern dry lands and Southern salinity prone areas of Bangladesh. There are other advantages of relay type of multiple cropping:

- There is no need for cultural operation like ploughing and soil preparation.

- Maximum benefit results from minimum cost.

- The soil texture and soil structure reach good condition.

- Large amount of soil moisture preserved as soil left undisturbed

- Less emission and more carbon storage as soil not exposed to drying and oxidation
- More soil microbes and other organisms preserved

The results from the relay cropping experiment also suggest comparable performance for yield components and yield (tillers 3.3 and yield per plant $5.5 \mathrm{~g}$ per plant) thus indicating that inter planting of wheat in the rice fields prior to harvest (relay cropping) can be a sustainable solution in salinity prone areas. Because of lack of rainfall and high evapo-transpiration in the dry Rabi season, the soil gets more saline with the mid and end of the season thus wheat facing more stress during the critical grain filling period. Also due to late withdrawal of monsoon resulting in late harvesting of Aman paddy, the time required for land preparation in traditional cropping becomes the cause of no wheat crop or very late sowing wheat resulting in low yield in the saline area. Thousands of small-scale rice farmers have seen their livelihoods decimated due to the effects of climate change related rainfall disturbances in the area. "Fast-increasing soil salinity, especially in agricultural lands, is a major problem in Bangladesh," said the Director of the Bangladesh Rice Research Institute (BRRI), over one million hectares of land have been seriously affected by salinity (IRIN, 2010).

The results reported indicated that relay cropping may be helpful in combating salinity stress, while growing wheat with zero tillage and soil conservation. A yield of $5.5 \mathrm{gm}$ per plat was obtained and the performances of the morphological characters were satisfactory. Comparable to those of farmers' fields, who grow small quantities of 


\section{Open Access Journal of Agricultural Research}

wheat under salinity for subsistence, wheat relay cropping may be a suitable alternative for increased wheat production by small farmers in T-aman paddy after harvest. This result indicates that relay cropping with modern variety will be more profitable. Similar result was also reported by $[24,25]$.

Wheat is the second most important cereal and lentil too, the second most important pulse crop in terms of area and production in Bangladesh [30]. With the existing farming procedure, loss of organic matter after tillage is particularly severe in the Tropics [31]. According to Lal zero tillage with better crop residue management can immensely help sequestering carbon in degraded lands, for an increase of 1 ton of soil carbon pool of degraded soils may increase crop yield by 20 to $40 \mathrm{~kg} / \mathrm{ha}$ for wheat, 10 to $20 \mathrm{~kg} / \mathrm{ha}$ for maize and 0.5 to $1 \mathrm{~kg} / \mathrm{ha}$ for cowpeas [32]. Conservation agriculture, like zero till is suitable for increasing infiltration and reducing run off and helping to reduce soil erosion. Also relay cropping in paddy fields use stubbles as a mulch providing good potential for increasing crop yield by conserving soil moisture, reduce evaporation, suppress weed infestation, enriching soil with nutrients from decomposing stubbles/roots [33,34]. Also, no-till improves soil quality (soil function), carbon, organic matter, soil aggregates, protecting the soil from erosion, evaporation of water, and structural breakdown. Recently, researchers at the Agricultural Research Service of the United States Department of Agriculture found that no-till farming makes soil much more stable than plowed soil. encourage farmers to engage in conservation tillage (http://www.extension.umn.edu/). Under such schemes, the farmers' land is legally redefined as a carbon sink for the power generators' emissions. Evidences suggests that no-till farming can be more profitable if performed correctly[35,36]. In 2000, the global area under zero tillage was estimated at 57 million ha, including 9.2 million ha in Argentina and 13.5 million ha in Brazil [37]. Rapid adoption of zero-tillage in the region, especially in India, began in the late-1990s. During 1997-2004, around 620,000 farmers adopted the system and zero tillage wheat cultivation now covers an estimated 1.76 million of the 14 million hectares of rice-wheat cultivation [38]. Conservation agriculture is attractive to farmers for several reasons: it saves time and money, it makes available a longer period for planting, it leads to greater drought tolerance and generally higher yields. Also a fairly large number of research reports demonstrated this advantage of zero tillage-relay cropping since 1970s in Asia and Africa [39-45].

\section{Why This Simple Good Agricultural Technology Is Not Rapidly Spreading?}

Despite these major advantages, in many countries including Bangladesh farmers are still not motivated in adopting such radical changes, lack of information, awareness and long term policy and promotion contributes to this. But in Brazil, the rapid expansion of this system is due to the farmers' active promoting of institutions like the Associations and networks which have been developed involving technicians and researchers from the Brazilian Zero Tillage Association for the Tropics (ZTAT) or the Clubes Amigos da Terra (CAT), resulting in very effective farmer-to-farmer spread and acceptance of the ideas and the technologies associated with zero till [33]. Further support for zero tillage promotion was generated by collaborating with ABEAS (Brazilian Association for Higher Agricultural Education) and the University of Brasilia in the first graduate-level correspondence course in zero tillage in Brazil, in 1999 [46-53]. The support-institutional, research and financial-required to tackle the local level ecosystem related problems, lack of enabling adaptability, absence of leadership and support innovation, poor understanding and implementation of the technology, lack of proof of value, reducing risks, sustaining performance and reliability are important here.

\section{References}

1. Evenson RE, Gollin D (2000) Assessing the impact of the Green Revolution, 1960 to 2000. Science 300(5620): 758-762.

2. World Bank (2007) World development report 2008: agriculture for development. Washington: World Bank.

3. Lichtfouse E, Navarrete $M$, Debaeke $P$, Souchère $V$, Alberola C, et al. (2009) Agronomy for sustainable agriculture. A review. Agronomy for sustainable development 29(1): 1-6.

4. Flora CB (2010) Food security in the context of energy resource depletion: Sustainable agriculture in developing countries. Renewable agriculture and food systems 25(2): 118-128.

5. Gomiero T, Pimentel D, Paoletti MG (2011) Is there a need for a more sustainable agriculture?. Critical reviews in plant sciences 30(1-2): 6-23. 


\section{Open Access Journal of Agricultural Research}

6. Lin BB, Chappell MJ, Vandermeer J, Smith G, Quintero E, et al. (2011) Effects of industrial agriculture on climate change and the mitigation potential of smallscale agro-ecological farms. $\mathrm{CAB}$ reviews: perspectives in agriculture, veterinary science, nutrition and natural resources 6(20): 2-18.

7. CIA (2011) The World Factbook Central Intelligence Agency.

8. Alam MS, ISLAM MA (2013) Long-term assessment of rice production scenario in bangladesh: a macro dynamics. Bangladesh J Agril Res 38(2): 257-269.

9. BBS (2008) BBS (Bangladesh Bureau of Statistics). Government of Bangladesh.

10. IPCC (2007) Climate Change 2007-Impacts, Adaptation and Vulnerability Contribution. Working Group II to the Fourth Assessment Report of the IPCC.

11. Crucefix D (1998) Organic agriculture and sustainable rural livelihoods in developing countries. Bristol: Soil Association.

12. Sanchez PA (2002) Soil fertility and hunger in Africa. Science 295(5562): 2019-2020.

13. Parrott N, van Elzakker B (2003) Organic and likeminded movements in Africa: development and status. Bonn: International Federation of Organic Agriculture Movements (IFOAM).

14. Giovannucci D, Scherr S, Milder JC, Nierenberg D, Hebebrand C, et al. (2012) Food and agriculture: the future of sustainability. A strategic input to the sustainable development in the 21st century (SD21) project. United Nations.

15. Pretty JN, Noble AD, Bossio D, Dixon J, Hine RE, et al. (2006) Resource-conserving agriculture increases yields in developing countries. Environmental science and technology 40(4): 1114-1119.

16. IFDC (2008) World fertilizer prices drop dramatically after soaring to all-time highs.

17. Bennett M, Franzel S (2013) Can organic and resource-conserving agriculture improve livelihoods? A synthesis. International Journal of Agricultural Sustainability 11(3): 193-215.
18. Belachew O, Zuberi MI (2015) Perception of Climate Change and Livelihood of a Farming Community of Maruf Kebele, Central Oromia, Ethiopia. American Journal of Climate Change 4(3): 269-281.

19. Ali MA, Ali M, Sattar M, Ali L (2010) Sowing date effect on yield of different wheat varieties. Journal of Agriculture Research 48(2): 157-162.

20. Irfaq M, Mumhammad T, Amin M, Jabbar A (2005) Performance of yield and other agronomic characteristics of four wheat genotypes under natural heat stress. International Journal of Botany 1(2): 124127.

21. Karim MR (2006) Brackish-water Shrimp Cultivation Threatens Permanent Damage to Coastal Agriculture in Bangladesh.

22. Hoanh CT, Tuong TP, Gowing JW, Hardy B (2006) Environment and Livelihoods in Tropical Coastal Zones: Managing Agriculture Fishery-Aquaculture Conflicts. Wallingford, Oxfordshire, GBR: CABI Publishing.

23. Nasrin A (2013) Study of wheat adaptations in the salinity affected areas of coastal Bangladesh. University of Rajshahi.

24. Gahoonia TS, Ali O, Sarker A, Rahman MM, Erskinve W (2005) Root traits, nutrient uptake, multi-location grain yield and benefit-cost ratio of two lentil (Lens culinaris, Medick.) varieties. J Plant and Soil 272: 153161.

25. Md Omar A, Md Zuberi I, Sarker A (2014) Management Practices for Lentil as Relay Crop in the Rice Based Cropping System. Journal of Agricultural Science and Technology 4: 126-134.

26. ACIAR (2009) Introduction of short duration pulses into rice-based cropping systems in western Bangladesh. Project CIM/2009/038 2011-15.

27. Kumar S, Singh R, Piggin C, Haddad A, Ahmed S, et al. (2011) No-till lentil: An option for profitable harvest in dry areas. GRAIN LEGUMES 57: 39-42.

28. Richards RA (1983) Should selection for yield in saline regions be made on saline or non-saline soils. Euphytica 32(2): 431-438. 


\section{Open Access Journal of Agricultural Research}

29. Wada Y, van Beek LPH, van Kempen CM, Reckman JWTM, Vasak S, et al. (2010) Global depletion of groundwater resources. Geophysical Research Letters $37(20)$.

30. BBS (2012) Government of Bangladesh.

31. Graham PH, Vance CP (2000) Nitrogen fixation in perspective: An overview of research and extension needs. Field Crop Res 65(2-3): 93-106.

32. Lal R (2004) Soil carbon sequestration impacts on global climate change and food security. Sci. 304(5677): 1623-1627.

33. FAO (2001) Soil management for small farms Strategies and methods of introduction, technologies and equipment. FAO.

34. ILEIA (1995) Centre for Information and Knowledge on Low External Input and Sustainable Agriculture. The Netherlands.

35. Beck DL, Miller JL, Hagny MP (2014) Successful NoTill on the Central and Northern Plains.

36. Derpsch R (2010) Economics of No-till farming. Experiences from Latin America.

37. FAO (2001) Conservation agriculture-Case studies in Latin America and Africa. FAO.

38. DFID (2014) Planting without ploughing: zero-till wheat takes root. CIMMYT pp: 1-6.

39. Aune JB, Asrat R, Teklehaimanot DA, Bune BT (2006) Zero tillage or reduced tillage: The key to intensification of the crop-livestock system in Ethiopia.

40. Pender J, Place F, Ehui S (2006) Strategies for Sustainable Land Management in the East African Highlands. International Food Policy Research Institute (IFPRI).

41. Gupta RK, Seth A (2007) A review of resource conserving technologies for sustainable management of the rice wheat systems of the Indo-Gangetic Plains. Crop Protection 26(3): 436-447.
42. Laxmi V, Erenstein O, Gupta RK (2007) Impact of Zero Tillage in India's Rice-Wheat Systems. CIMMYT and RWC Research Report.

43. Erenstein O, Malik RK, Singh S (2007) Adoption and Impacts of Zero Tillage in the Rice-Wheat Zone of Irrigated Haryana, India. CIMMYT and the Rice Wheat Consortium for the Indo-Gangetic Plains, New Delhi.

44. Jabbar A, Ahmad R, Bhatti IH, Aziz T, Nadeem M, et al. (2011) Residual soil fertility as influenced by diverse rice-based inter/relay cropping systems. Int J Agric Biol 13: 477-483.

45. Mesfin T, Moeller C, Rodriguez D, Temesgen M (2011) Conservation Agriculture in Dryland Agro-ecosystems of Ethiopia. World Congress on Conservation Agriculture 2011 Papers. 5th World Congress on Conservation Agriculture and Farming Systems Design, Brisbane, Australia.

46. Tripathi RS, Raju R, Thimmappa K (2013) Impact of Zero Tillage on Economics of Wheat Production in Haryana. Agricultural Economics Research Review 26(1): 101-108.

47. Landers JN (2001) Zero Tillage development in tropical Brazil. FAO 147.

48. Bhushan L, Ladha JK, Gupta RK, Singh S, Tirol Padre A, et al. (2007) Saving of water and labour in rice-wheat system with no tillage and direct seeding technologies. Agronomy Journal 99(5): 1288-1296.

49. Erenstein O, Farooq U, Malik RK, Sharif M (2008) Onfarm impacts of zero-tillage wheat in South Asia's rice-wheat systems. Field Crops Research 105(3): 240-252.

50. FAO (2014) Bridging the rice yield gap in the AsiaPacific region.

51. FAO (2011) Crop Prospects and Food Situation. Global Information and Early Warning System, FAO.

52. Headey DD, Hoddinot J (2016) Agriculture, nutrition and the green revolution in Bangladesh. Agricultural Systems 149: 122-131.

53. Hossain M, Bayes A, Islam SMF (2017) A Diagnostic Study on Bangladesh Agriculture. 
(c) 